GEOLOGICA BALCANICA, 49 (3), Sofia, Dec. 2020, pp. 3-12.

\title{
Fossil holothurian ossicles from the lower Toarcian of the Balkan Mts, Bulgaria
}

\author{
Lubomir Metodiev, Silviya Petrova, Elena Koleva-Rekalova, \\ Georgi Granchovski
}

Geological Institute, Bulgarian Academy of Sciences, Acad. G. Bonchev Str., Bl. 24, 1113 Sofia, Bulgaria; e-mails: lubo@geology.bas.bg; silviya_p@geology.bas.bg; e_koleva@geology.bas.bg; georgi2801@geology.bas.bg

(Accepted in revised form: October, 2020)

\begin{abstract}
Fossil holothurian ossicles from three localities of the lower Toarcian in the Balkan Mts (Bulgaria), assigned to the family Chiridotidae and the parafamilies Theeliidae, Priscopedatidae and Calclamnidae, were studied. Two types of ossicles and four morphogenera were described: 1) wheels, among which Palaeotrochodota (abundant) and Theelia (single specimens); and 2) perforated ossicles, including Priscopedatus and Cucumarites (both in single specimens). These fossils are well known in Europe but have not been recorded in Toarcian rocks from Bulgaria to date. The studied fauna remains of undetermined palaeoenvironmental significance, although the high morphological variability and abundance of Palaeotrochodota seem potentially informative.
\end{abstract}

Metodiev, L., Petrova, S., Koleva-Rekalova, E., Granchovski, G. 2020. Fossil holothurian ossicles from the lower Toarcian of the Balkan Mts, Bulgaria. Geologica Balcanica 49 (3), 3-12.

Keywords: holothurian ossicles, lower Toarcian, Balkan Mts, Bulgaria.

\section{INTRODUCTION}

The Class Holothuroidea (sea cucumbers, holothurians) comprises over 1700 known species and includes deposit-feeding and suspension-feeding animals of worldwide distribution that, to date, have been found in both shallow warm waters and the deep sea (e.g., Miller et al., 2017). It is known that sediment systems may demonstrate different levels of primary production, which usually decreases with depths (e.g., Roberts et al., 2000, and references therein). It is also known that most sedimentary environments have little or no primary production and receive organic matter mainly by sinking or by horizontal transfer (e.g., Valiela, 2015; Middelburg, 2019). Sea cucumbers have to ingest large amounts of sediments to meet their vital needs. Thus, the occurrence of holothurians is largely determined by the composition of the bottom sediments as sources of food material. Modern sea cucumbers may play an essential role in marine ecosystems, as they are actively involved in the decomposition of organic matter and reworking of sea-bottom sediments. Feeding experiments with modern holothurians have demonstrated that the organic component in the sediments can substantially be changed, both in quality and in amount, as a result of their activity (Xu et al., 2015).

Sea cucumbers are animals of ancient origin, characterized by worldwide distribution, richness of forms and high adaptability. Being creatures with an endoskeleton, however, holothurians are extremely rare as body fossils, and thus their history in the geological past is still poorly known. The fossil record of holothurians predominantly consists of isolated calcified structures (ossicles), which may compose abundant microfossil assemblages. In recent summaries on the species diversity of fossil holothurians, more than 960 published paraspecies/species names have been listed (Reich, 2012, 2013, 2014, 2015). Albeit with significant gaps, the holothurian fossil record has generally been drawn, and it has been assumed that those animals have a long total chronostratigraphical extent, from the Ordovician 
to the Quaternary (ibid.). As stated by Reich (2013), more than two-thirds of the available names can be considered valid. Of these, the Triassic and Jurassic taxa are the most numerous, and thus dominate the holothurian fossil data from the Phanerozoic.

In Bulgaria, only a few holothurian ossicles from the Middle Triassic (Stefanov, 1970) and from reworked Devonian carbonates (Ebner et al., 1976; Ebner and Fenninger, 1980) have been described and figured to date. The presence of ossicles has sporadically been noted in previous Bulgarian sedimentological literature, but no one has paid special attention to them. The same holds true to the sediments of the Bulgarian Jurassic. Given the relatively rich data from Europe and the fact that Bulgarian Jurassic rocks have both facial and coeval European equivalents, the Bulgarian fossil record of holothurians should be similar to that from elsewhere. In spite of that, Jurassic holothurians remain completely unknown in Bulgaria. The present paper provides the first data on the presence of holothurian ossicles in the Lower Jurassic strata of Bulgaria. The fossil material represented below was accidentally found during the study of lower Toarcian sedimentary intervals as potential recorders of the Early Toarcian Oceanic Anoxic Event (ETOAE). The aim of this account is not to go deeply into taxonomic details, but to report the holothurian presence as a curious fact that could later be interpreted elsewhere in the light of the ETOAE and its impact on the marine benthic communities.

\section{GEOLOGICAL BACKGROUND, HOLOTHURIAN LOCALITES AND MATERIAL}

The Balkan Mountains area, including the foothills of the Fore-Balkan Mts, is a W-E trending mountain region, which consists of various folded and thrust Paleozoic and Mesozoic rocks. From a structural point of view, this region represents the Balkan Zone, which is the external northern part of the Balkan orogen in Bulgaria (Dabovski et al., 2002). Jurassic sediments are an integral part of the thick Mesozoic cover and have a wide outcrop occurrence in the Balkan Zone (Fig. 1a). These rocks are particularly well developed in the Western Balkan and in the Central Fore-Balkan Mts, where they take part of some prominent positive structures of the Balkan Zone, those of the Zimevitsa Plateau and the Teteven Arch. Mixed shallow- to moderately deeper-marine siliciclastic and carbonate sediments represent the Lower-Middle Jurassic rocks of these structures. These transgressive deposits largely correspond to the Ozirovo Formation, which spans the late Hettangian to the early Bajocian, and their general lithostratigraphy was summarized by Sapunov and Metodiev (2007). They have long been known for their abundant fossils. Locally, two fossil fields from the Western Balkan Mts area, called Dobravitsa-1 and Bov (Fig. 1b), and one field from the Central Fore-Balkan Mts, called Varbanchovets (Fig. 1c), supplied the material for this study. These fields are parts of previously studied sections that refer to the Bukorovtsi Member of the Ozirovo Formation (Metodiev and Koleva-Rekalova, 2008; Metodiev et al., 2014, 2019).

Section Dobravitsa-1 comprises a 7-m thick succession of alternating marlstones, shales and limestones, in which abundant ammonites and belemnites are the main macrofossils present (see Metodiev and Koleva-Rekalova, 2008). A subordinate fauna of brachiopods and bivalves was also found. This succession was subdivided into 15 ammonite zones, from the upper Pliensbachian Pleuroceras spinatum Zone at the base to the lower Bajocian Hyperlioceras discites Zone at the top (ibid.). The holothurian ossicles came from a $0.2-\mathrm{m}$ thick bed, which consists of grey ferruginized crinoidal wackestones with phosphate nodules (see Fig. $2 a-c$ ). The rocks are composed of dark brown matrix, with common fine dolomite rhombohedra, a moderate number of allochems (mainly crinoidal bioclasts, but also shell fragments and benthic foraminifera, hollow spines of echinoids, sponge spicules and single ossicles of Holothuroidea), and a small number of terrigenous components (including silt-sized quartz and muscovite). This bed refers to the lower Toarcian Dactylioceras (Orthodactylites) tenuicostatum ammonite Zone [D. (O.) crosbeyi ammonite Subzone].

Section Bov (5 m thick) consists of alternating silty carbonaceous shales and limestones (ferruginized bioclastic wackestones, recrystallized microsparite limestones and pyritized clayey limestones), with sporadically preserved ammonites and belemnites and an ammonite zonal extent, previously defined, from the lower Toarcian Harpoceras falciferum ammonite Zone to the upper Toarcian Haugia variabilis ammonite Zone (Metodiev et al., 2019). The holothurian ossicles were found in two concretionary beds, each $0.2 \mathrm{~m}$ thick, which are herein referred to the very base of the succession. The latter beds are composed of a few centimetres in diameter subglobular nodules surrounded by a strongly altered iron-sulphide matrix. The rocks composing the nodules are carbonatized ferriferous ooidal wackestones and they have high content of micrite matrix, a moderate number of allochems and single terrigenous components (see Fig. $2 d-f$ ). The matrix of the nodules is either well preserved or recrystallized into 


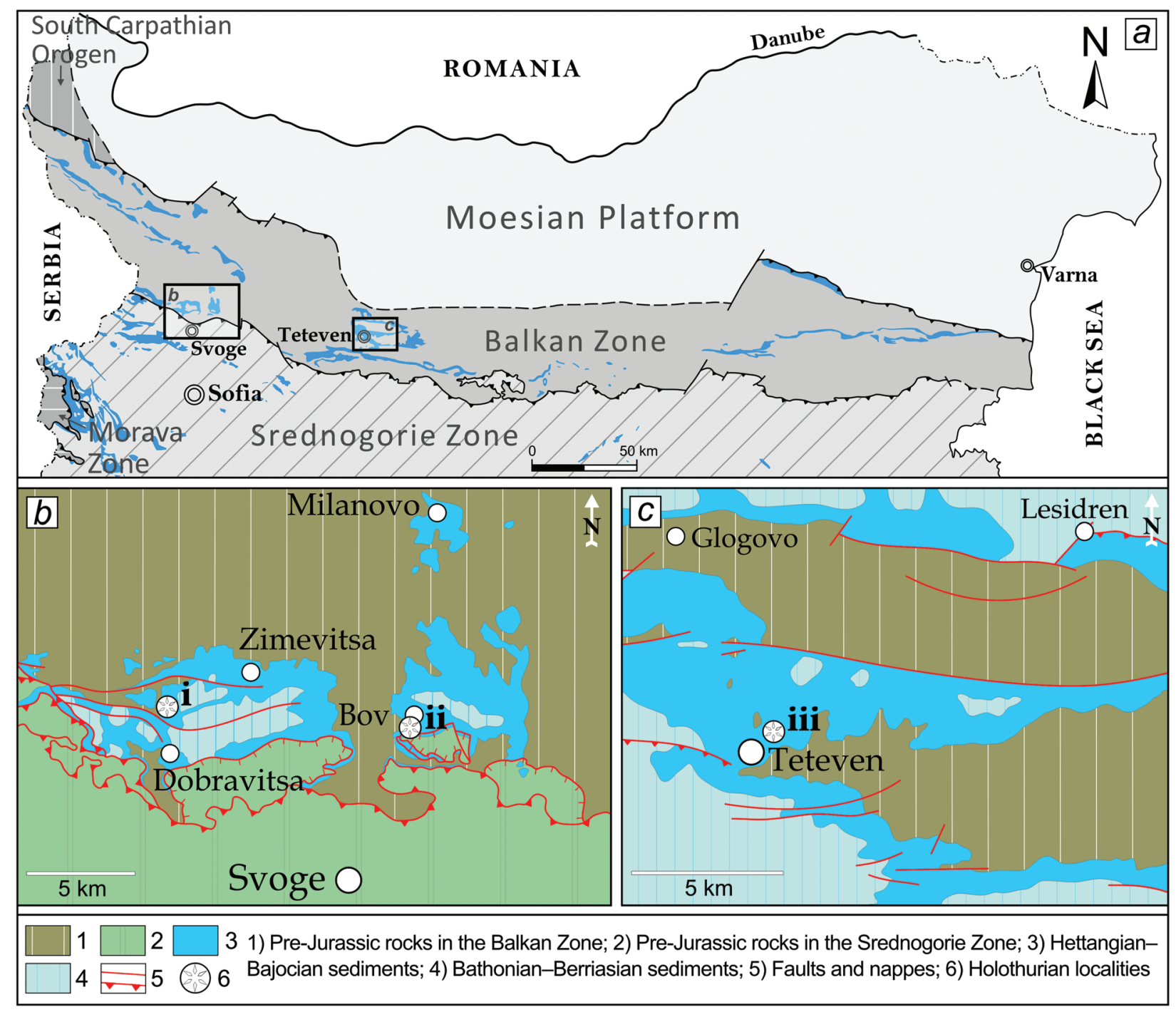

Fig. 1. a) Outcrops of Jurassic rocks (blue) on the simplified tectonic map of Bulgaria (after Sapunov and Metodiev, 2007, and Dabovski et al., 2002); b) geological sketch map of the Zimevitsa Plateau and the adjacent areas (Western Balkan Mts), showing the locations of the holothurian localities Dobravitsa-1 (i) and Bov (ii); $\boldsymbol{c}$ ) geological sketch map of the Teteven Arch (Central ForeBalkan Mts) with location of the field Varbanchovets (iii).

microsparite. The allochems correspond, in order of decreasing abundance, to carbonatized iron ooids, sponge spicules, holothurian ossicles, crinoids, shell fragments and benthic foraminifera. The concretionary beds are conditionally attributed to the lower Toarcian D. (O.) tenuicostatum ammonite Zone.

Section Varbanchovets corresponds to a 3.3-m thick rock interval, located near the northern end of the town of Teteven. It consists of ferruginized ooid-bearing marlstones and shales, interbedded with Fe-ooid-bearing bioclastic limestones that were stratigraphically placed from the lower Toarcian $D$. (O.) tenuicostatum ammonite Zone [D. (O.) semicelatum ammonite Subzone] to the upper Toarcian Pseudogrammoceras fallaciosum ammonite Zone
(Metodiev et al., 2014). The fossil record of the section consists of abundant ammonites, blended with numerous belemnite rostra (ibid.). The holothurian ossicles were recognized into a $0.2-\mathrm{m}$ thick bed of dark grey to bluish marlstones. The rocks contain common deformed iron ooids and small phosphate nodules. They are composed of calcareous-clayey matrix, comprising an abundant ossicle assemblage, rare crinoidal bioclasts, ostracods, brachiopods and common foraminifera (see Fig. $2 g-i$ ). Also present are angular to sub-rounded grains of quartz, feldspar and lithoclasts with silt to fine-sand size. According to the ammonite occurrence, this bed refers to the lower Toarcian Hildoceras bifrons ammonite Zone (Hildoceras lusitanicum ammonite Subzone). 

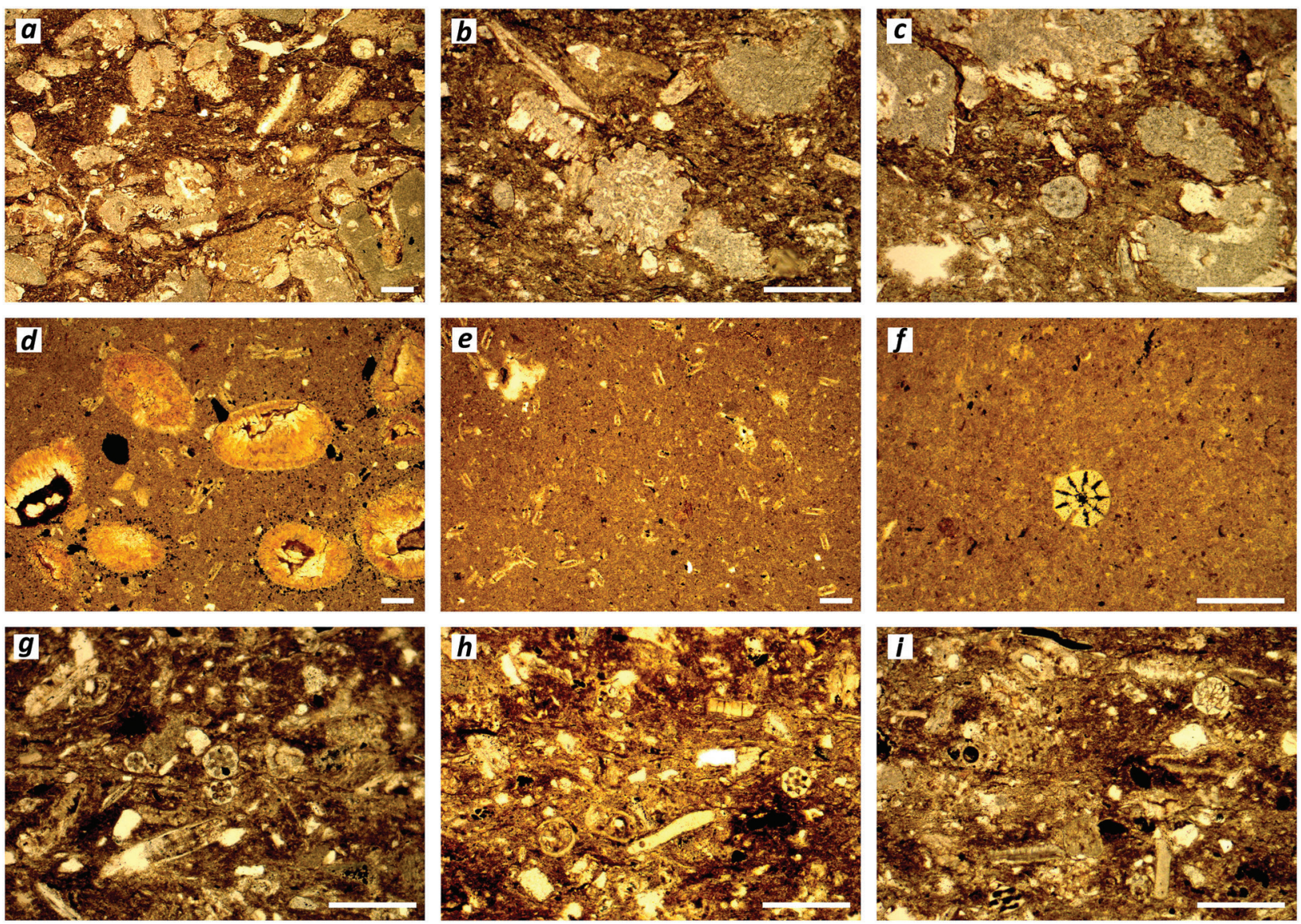

Fig. 2. Photomicrographs representing the rocks, in which the holothurian ossicles were found. Plane-polarized light. Scale bars $=200 \mu \mathrm{m}$. $a-c$ ) Ferruginized crinoidal wackestones (Dobravitsa-1): (a) abundant crinoidal bioclasts in brown micrite matrix with some indistinct dissolution seams and rare quartz grains; $(b)$ crinoidal bioclasts, shell fragments and a hollow echinoid spine in brown micrite matrix containing sporadic quartz grains; $(c)$ crinoidal bioclasts and a holothurian wheel in brown micrite matrix containing single rhombohedral dolomite crystals, quartz grains and muscovite flakes.

$d-f)$ Carbonatized ferriferous ooidal wackestones (Bov): $(d)$ carbonatized ferriferous ooids in micrite matrix; $(e)$ abundant fragments of calcitized sponge spicules in micrite matrix; $(f)$ holothurian wheel in brown micrite matrix.

$g-i$ ) Ferriferous ooid-bearing marlstones (Varbanchovets): $(g)$ small crinoidal bioclasts and holothurian wheels in brown micrite matrix containing quartz grains; $(h)$ abundant crinoidal and shell fragments, common foraminifera and a single holothurian wheel in brown micrite matrix containing rare quartz grains; (i) shell and crinoidal bioclasts and holothurian wheels in brown micrite matrix containing rare quartz grains.

A total of 185 body wall ossicles of Holothuroidea (five from Dobravitsa-1, 52 from Bov and 128 from Varbanchovets) were recognized in four petrographic thin-sections. The bulk of the specimens under discussion represent wheel-like holothurian ossicles. Flat perforated ossicles were also studied. The terminology and systematics used herein follow those of Reich (2012), although earlier publications (e.g., Frizzell and Exline, 1956; Deflandre-Rigaud, 1962) have also been taken into account. The taxonomic definitions were made to a generic level since some valuable morphological species traits were not seen in thin-sections. The material described is housed at the Laboratory for Geocollections at the Geological Institute of the Bulgarian Academy of Sciences.

\section{SYSTEMATIC PALAEONTOLOGY}

\section{Class Holothuroidea de Blanville, 1834 \\ Subclass Paractinopoda Ludwig, 1891 \\ Order Apodida Brandt, 1835 \\ Family Chiridotidae Östergren, 1898}

\section{Paragenus Palaeotrochodota Reich, 2003}

(Fig. 3a-y; Fig. 4a-l)

Type species: Palaeotrochodota jagti Reich (2003, p. 370, figs 1, 2; fig. $1 / \mathrm{B}_{1}-\mathrm{B}_{2}-\mathrm{FGWG} 237 / 1$, SEM 102164a-c, holotype), by original designation; from glacial erratic boulder near Dargelin (Western Pomerania, Germany), upper Maastrichtian. The holotype is kept in the collections of the Institute 
of Geological Sciences at the University of Greifswald, Germany.

Material and record. One hundred and twentytwo ossicles from Varbanchovets (thin-section Inv.-Nr SR.010483.ts), lower Toarcian, $H$. bifrons Zone (H. lusitanicum Subzone); 50 ossicles from Bov (thin-sections Inv.-Nrs MF.SR.016953 and MF.SR.016954), lower Toarcian, D. (O.) tenuicostatum Zone; two ossicles from Dobravitsa-1 (thinsection Inv.-Nr MF.SR.006246.ts ${ }_{1}$ ), lower Toarcian, D. (O.) tenuicostatum Zone [D. (O.) crosbeyi Subzone].

Description. According to Reich (2003, pp. 370, 378), this paragenus includes round to polygonal and concavo-convex wheels with outer rim, which bears smooth subtriangular arcs that may vary from 6 to 9 and correspond in number to the spokes. The arc apex points to the centre of the hub. The spoke width increases towards the hub. The diameter of the wheels in the samples of the type series varies from $100 \mu \mathrm{m}$ to $280 \mu \mathrm{m}$.

The specimens in the present collection consist of wheel-like ossicles with a round to sub-polygonal outline that vary in diameter from $80 \mu \mathrm{m}$ to $140 \mu \mathrm{m}$. They are composed of a central part (hub), from which 6 to 9 spokes diverge radially and connect to a thin outer rim. In 40 per cent of the ossicles, the spokes are 6 or 7 , and wide rhomboidal to leaf-like marginal perforations are open between them (see Fig. $3 a-r)$. For the rest, those with 8 or 9 perforations are almost equal in number in the association and the spoke interspaces are commonly narrower and lanceolate (see Figs $3 x, y$; $4 c-h$ ). The marginal perforations are filled with sedimentary material from the host rock, which is often pyritized. The spokes are short, narrower near the middle, and extend to both the outer edge and the hub. Large subtriangular arcs, with tips pointing towards the centre of the wheel, are placed against each spoke. In most of the specimens, both the arcs and the spokes recrystallized into a homogeneous mass of very fine-grained calcite. Only in single ossicles can it be seen that the arcs and the spokes are composed of well-defined transparent calcite crystals. In some smaller ossicles, the outer rim is interrupted and the arcs are rounded and not in contact with each other (see Fig. 3d, e, r). The hub/ wheel diameter ratio is 0.20 to 0.40 . The hubs are usually not solid and, similarly to the marginal perforations, can be filled with either material from the enclosing sedimentary rock or pyritized sediment. In some specimens, the hub consists of an inner rosette and an outer ring between the spokes, both made of 6 bipyramidal calcite crystals (see Fig. $3 h, k, l$ ).

Discussion. The Bulgarian material as a whole agrees with the type specimens, on which the genus
Palaeotrochodota was defined, but it shows, however, a smaller diameter, stouter arcs and shorter spokes, and also a wider variation in the shape of the marginal perforations. The structure of the hub and the outer rim are not visible in detail in the sections, and therefore a reliable species determination is not possible. Another difference is the significant distance in time between the Bulgarian ossicles, which are Early Jurassic in age, and those of the type series of this paragenus, which are from the Late Cretaceous. It is difficult to decide whether the studied wheels are skeletal elements from one or several different parent animals. Taking into account the age range of the Bulgarian localities, both options seem possible. According to the emended use of Palaeotrochodota (Reich, 2003, p. 380), in addition to the Upper Cretaceous forms, this paragenus also includes Jurassic representatives. Reich (ibid.) referred to it the wheels defined as Hemisphaeranthos ogrodzieniecensis, from the middle Bathonian of Poland (Górka and Łuszczewska, 1969, p. 381, pl. 78, figs 6,7$)$. The latter finds are similar in morphology to both the type species for Palaeotrochodota and the Bulgarian ossicles and could, therefore, be interpreted as an intermediate element in the overall fossil record of the paragenus. The Polish forms are dissimilar, however, in the arrangement of the arcs and the shape of the marginal perforations.

Occurrence. Lower Toarcian (Bulgaria). Middle Bathonian (Poland). Upper Cretaceous (Maastrichtian), Netherlands, southern Baltic Sea.

\section{Parafamily Theeliidae Frizzell \& Exline, 1956 Paragenus Theelia Schlumberger, 1890}

(Fig. $4 m-O$ )

Type species: Chirodota undulata Schlumberger (1888, p. 439, text-fig. 7; 1890, p. 197, figs 13, 14), from the Eocene of France.

Material and record. Three ossicles: Varbanchovets (thin-section Inv.-Nr SR.010483.ts), lower Toarcian, $H$. bifrons Zone (H. lusitanicum Subzone); Bov (thin-section Inv.-Nr MF.SR.016953), lower Toarcian, D. (O.) tenuicostatum Zone; Dobravitsa-1 (thin-section Inv.-Nr MF.SR.006246.ts ${ }_{1}$ ), D. (O.) tenuicostatum Zone [D. (O.) crosbeyi Subzone].

Description. Ossicles with a circular outline, smooth and slightly undulating outer rim, and a diameter between $160 \mu \mathrm{m}$ and $300 \mu \mathrm{m}$. The central part is composed of either a small and rounded hub, which appears to lie below the surface of the rim (Fig. $4 m$ ), or a rosette of calcite crystals, which correspond in number to, and are developed below, the spokes (Fig. 4n, o). Seven to nine radial spokes 

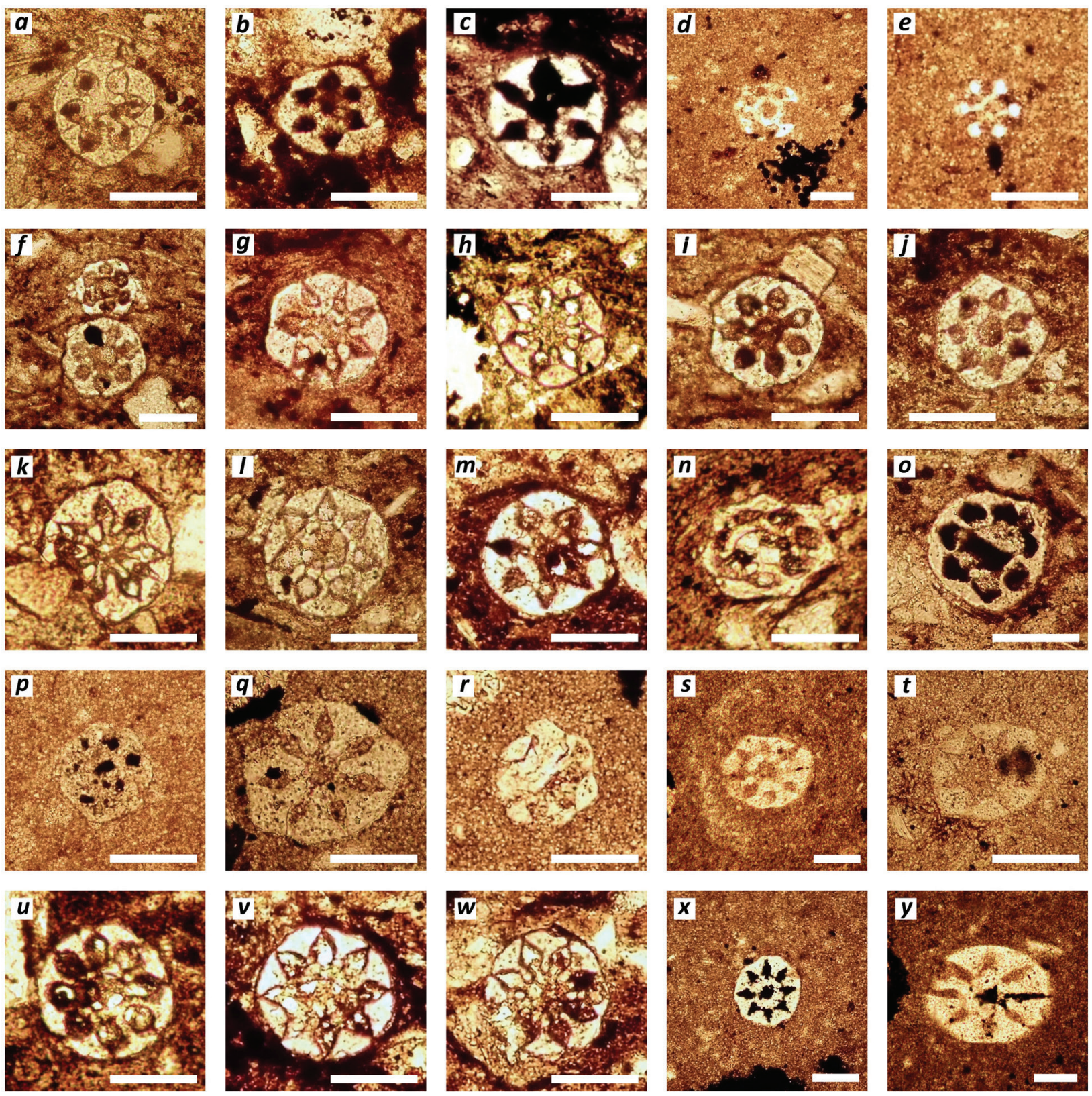

Fig. 3. Wheel ossicles of the paragenus Palaeotrochodota from the lower Toarcian of the Balkan Mts: $a-f)$ wheels with 6 spokes; $f-r)$ wheels with 7 spokes; $s-y)$ wheels with 8 spokes. Localities: Varbanchovets $(a-c, f-o, u-w)$; and Bov $(d, e, p-t, x, y)$. Planepolarized light. Scale bars $=100 \mu \mathrm{m}$.

may diverge from the central part and connect to a relatively wide outer rim. The spokes seem concave to slightly concave, moderately thick and connected directly at the centre of the wheel, without any evident structural complications. The outer rim has edges that are curved inwards. The marginal perforations are broad and triangular, tapering towards the centre of the wheel.

Discussion. Both the degree of preservation and the scarcity of material prevent identification at species level. Morphologically, our specimens resemble two Jurassic paraspecies, Theelia liassica Mostler (in: Krainer et al., 1994) and T. heptalampra (Bartenstein, 1936), but this assumption could be assesses by further isolation of sufficient material and SEM studies.

Theelia liassica was published in a list of paraspecies from the Northern Calcareous Alps (Austria) and figured by a single wheel (Krainer et al., 1994, pl. 4, fig. 4), but neither diagnosed nor described. It appears to have sufficiently distinct characteristics and must, therefore, be properly sta- 

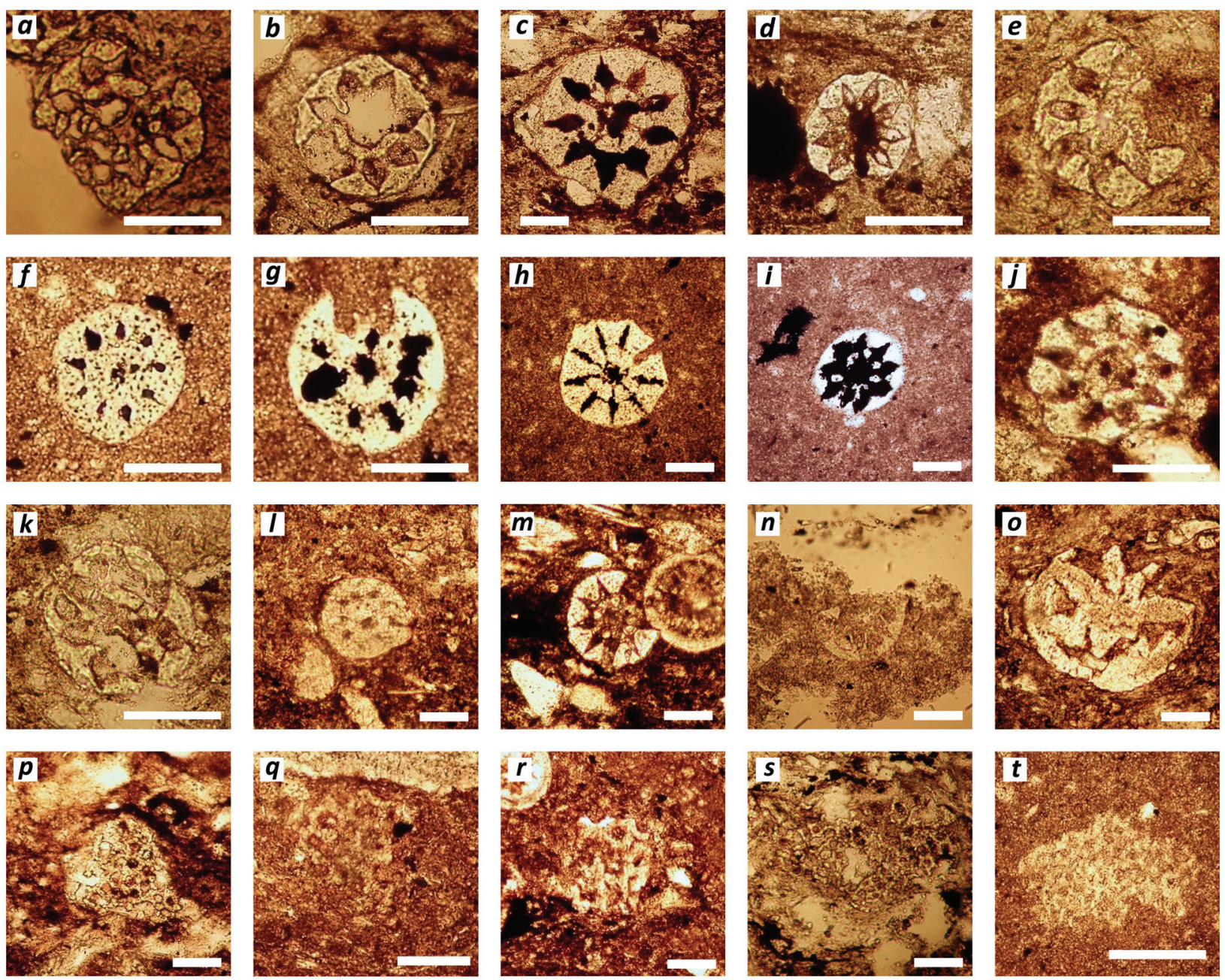

Fig. 4. Wheels and perforated ossicles from the lower Toarcian of the Balkan Mts: $a-m)$ wheels of Palaeotrochodota with 9 spokes, Varbanchovets ( $a-e, m$ - left specimen), Bov $(f-j)$; Dobravitsa-1 $(l) ; m-o$ ) wheels of Theelia, Varbanchovets (m, the right specimen), Bov ( $n$ ) and Dobravitsa-1 (o); $p-r$ ) perforated ossicles of Priscopedatus, Varbanchovets ( $p$ ) and Dobravitsa-1 $(q, r) ; s, t)$ perforated ossicles of Cucumarites, Varbanchovets $(s)$ and Bov $(t)$. Plane-polarized light. Scale bars $=100 \mu \mathrm{m}$.

bilized in the nomenclature. A few other Jurassic wheels, with different species definitions similar to $T$. liassica, were also figured by Krainer et al. [1994, pl. 4: fig. 1 (T. variabilis Zankl); figs 2, 3, 10 (? Theelia florida (Terquem \& Berthelin); fig. 5 (T. immissorbicula Mostler); fig. 6 (Theelia sp.); figs 7, 8 (T. multiundulata Mostler); figs 9, 13, 14 (T. loferensis Mostler)] but not supported by proper descriptions either. Albeit varying in number, the spokes in these forms show a fairly similar morphology to that of $T$. liassica, but there are distinctions in the shape of the outer rim, as well as in the size of the hub.

Theelia heptalampra is an often-recorded holothurian paraspecies from the Jurassic of Europe (e.g., Rioult, 1961; Frentzen, 1964; Górka and Łuszczewska, 1969; Krainer et al., 1994; Reolid et al., 2019). The seven-spoke ossicles illustrated herein (Fig. 4n, o) are with poorly visible central part and outer rim, so they are not comparable with ossicles from the listed literature. Some authors tend to synonymize T. heptalampra with Theelia convexa (Whidborne, 1883) (Lord and Senior, 1973, pl. 1, figs 1a-b, refigured holotype with better quality than the original publication), with the latter species taking priority (see Gilliland, 1992, pp. 189-192; see also Lipiec, 1992). We note such decisions since these specific names correspond to very similar morphologies with minor differences, and therefore our wheels could potentially also refer to $T$. convexa. In $T$. convexa, however, there is a fine denticulation along the inner margin of the rim, which is not seen in our ossicles. 
Occurrence. Carboniferous (China, USA); Permian (Iran); Triassic (Austria, Italy, Germany, Hungary, Romania, Slovakia, Spain, Turkey); Jurassic (Hettangian-Kimmeridgian), Austria, Bulgaria, Egypt, Poland, Portugal, U.K.; Lower Cretaceous (upper Valanginian; Aptian-Albian), Austria, Poland; Upper Cretaceous (upper Maastrichtian), Germany and southern Baltic Sea; Eocene (France); Neogene (Austria).

\section{Subclass Actinopoda Ludwig, 1891 Parafamily Priscopedatidae Frizzell \& Exline, 1956}

Paragenus Priscopedatus (Schlumberger, 1890) emend. Deflandre-Rigaud, 1962

(Fig. $4 p-r$ )

Type species: Priscopedatus pyramidalis Schlumberger (1888, p. 201, figs 26-29), from the Eocene of France.

Material and record. Three ossicles: one from Varbanchovets (thin-section Inv.-Nr SR.010483.ts), lower Toarcian, $H$. bifrons Zone $(H$. lusitanicum Subzone); and two from Dobravitsa-1 (thin-section Inv.-Nr MF.SR.006246.ts 1 ), lower Toarcian, D. (O.) tenuicostatum Zone [D. (O.) crosbeyi Subzone].

Description. Round to oval ossicles with numerous round to subpolygonal, irregularly arranged and smooth-edged perforations. The plates appear slightly convex, measuring between $200 \mu \mathrm{m}$ and $220 \mu \mathrm{m}$ in length and $140-200 \mu \mathrm{m}$ in width. One of the specimens (Fig. $4 p$ ) seems to be completely preserved, while the other two (Fig. 4q, $r$ ) probably represent fragments of bigger skeletal elements. In the plate corner of the former specimen, a conical elevation with smooth cross-wise clasp that rises above 4 close perforations is visible. In addition, the perforations in this specimen become unevenly larger towards the periphery of the plate. The fragmented ossicles are slightly convex and display invariable in size subpolygonal perforations.

Discussion. Priscopedatus is a well-known holothurian paragenus with wide stratigraphical range, including the Jurassic, and common occurrence in Europe (see Reich, 2013). Over 30 available names are known from the Jurassic, but most of them are Middle to Late Jurassic in age (ibid.). Of these, three paraspecies are approximately coeval and akin to our material, namely $P$. empeldensis Kristan-Tollmann, P. acutus Mostler and P. variabilis Mostler. Priscopedatus empeldensis is an upper Pliensbachian holothurian paraspecies defined from Germany (Kristan-Tollmann in: Fischer et al., 1986, p. 132, pl. 29, figs 10-14), to which the ossicles presented herein are similar, but what we have is not sufficient, both as number of specimens and preservation, and therefore we only conditionally refer them to Priscopedatus. Both $P$. acutus and $P$. variabilis differ from $P$. empeldensis in having smaller ossicles, in which strongly protruding cruciform and nodular elements, located between 4 larger perforations, exist. The latter morphological features were not seen in the Bulgarian specimens.

Occurrence. Carboniferous (Afghanistan, China, USA); Permian (Iran); Triassic (Austria, Bulgaria, Germany, Italy, Montenegro, Poland, Slovakia); Jurassic (Hettangian-Kimmeridgian), Austria, Bulgaria, Egypt, France, Germany, Poland; Cretaceous (upper Valanginian-upper Cenomanian), Jordan, USA, Poland; Oligocene-Eocene (France, Germany).

\section{Parafamily Calclamnidae Frizzell \& Exline, 1956}

\section{Paragenus Cucumarites Deflandre-Rigaud, 1949} (Fig. 4s, $t$ )

Type species: Cucumarites mortenseni (Frizzell and Exline, 1956, p. 88, pl. 3, fig. 5), by original designation (Deflandre-Rigaud, 1959, p. 191), from the Lower Jurassic of Germany.

Material and record. Two ossicles: one from Varbanchovets (thin-section Inv.-Nr SR.010483.ts), lower Toarcian, $H$. bifrons Zone $(H$. lusitanicum Subzone); and one from Bov (thin-section Inv.-Nr MF.SR.016953), lower Toarcian, D. (O.) tenuicostatum Zone.

Description. Ossicles of irregular (polygonal rounded) shape, in the form of a flat to slightly convex perforated plate. The specimens are incomplete, with partly visible lateral margin. The peripheries of the plates are incised. The perforations are numerous, small, irregularly arranged and polygonal. The plates have dimensions of 1501 Í30 $\mu \mathrm{m}$ and 2001 Í320 $\mu \mathrm{m}$, while the perforations are of a size $\sim 10 \mu \mathrm{m}$.

Discussion. The available Bulgarian specimens are similar in morphology to the perforated ossicles from the Upper Jurassic (Oxfordian) of Normandy (France), described by Deflandre-Rigaud (1962, pp. 52-61), but have bigger plate dimensions. In addition, the French material consists of specimens, in most of which the perforations are rounded, varying in size, often even in individual specimens, and some arrangement can be observed. Closer in age to our specimens are the ossicles of Cucumarites from the upper Bajocian and the Bathonian of Poland (see Górka and Łuszczewska, 1969, pp. 376, 377). The latter material, however, consists of fragments of perforated plates, with which it is difficult to make a comparison. 
Occurrence. Upper Triassic (Austria, India, Germany); Jurassic (Oxfordian-lower Toarcian), Bulgaria, France, Germany, India, Poland; Albian (Hungary); lower Maastrichtian (Germany); Oligocene-Miocene (Austria, Germany, France).

\section{Acknowledgements}

This work was carried out in the framework of the National Science Program "Environmental Protec- tion and Reduction of Risks of Adverse Events and Natural Disasters", approved by the Resolution of the Council of Ministers No. 577/17.08.2018 and supported by the Ministry of Education and Science (MES) of Bulgaria (Agreement No. D01322/18.12.2019). We are grateful to Dr Mike Reich (Bayerische Staatssammlung für Paläontologie und Geologie, Munich, Germany) for his highly constructive suggestions and comments on an early version of the manuscript.

\section{REFERENCES}

Bartenstein, H. (1936). Kalk-Körper von Holothurien in norddeutschen Lias-Schichten. Senckenbergiana 18 (1/2), 1-10.

Blainville, H.M.D. de. 1834. Manuel d'actinologie ou de zoophytologie. F.G. Levrault. Paris, Strasbourg, 644 pp.

Brandt, J.F. 1835. Prodromus descriptionis animalium ab $\mathrm{H}$. Mertensio in orbis terrarum circumnavigatione observatorum. Animalia Mertensii. Petropoli, Lipsiae 1, 1-75.

Dabovski, C., Boyanov, I., Khrischev, Kh., Nikolov, T., Sapunov, I., Yanev, Y., Zagorchev, I. 2002. Structure and Alpine evolution of Bulgaria. Geologica Balcanica 32 (3-4), 9-15.

Deflandre-Rigaud, M. 1946. Sur les divers types de sclérites d'Holothurides oxfordiens des marnes de Villers-sur-Mer. Comptes rendus de l'Académie des Sciences Paris 223, 513-515.

Deflandre-Rigaud, M. 1949. Quelques observations sur les spicules d’Éponges calcaires fossiles. Microscopie 1 (4), 151-161.

Deflandre-Rigaud, M. 1959. Sur quelques sclérites d’Holothurides de l'Oligocène d'Innien, Holstein. Revue de Micropaléontologie 1 (4), 190-200.

Deflandre-Rigaud, M. 1962. Contribution à la connaissance des sclérites d'Holothurides des fossiles. Mémoires du Muséum National d'Histoire Naturelle, Série C, Sciences de la Terre 11, 1-124.

Ebner, F., Fenninger, A. 1980. Mikrofacies und Biostratigraphie der Kalkgerölle von Falcovec (NW-Bulgarien). Palaeontology, Stratigraphy and Lithology 12, 3-12.

Ebner, F., Fenninger, A., Flügel, H.W. 1976. Kenntnis der Devonkalk-Gerölle von Borovica bei Belogradčik (NWBulgarien). Review of the Bulgarian Geological Society 37 (3), 249-255.

Frentzen, K. 1964. Funde von Holothurien-Kalkköperchen im Jura des Oberrheingebiets. Beiträge zur naturkundlichen Forschung in Südwestdeutschland 23 (1), 31-51.

Frizzell, D.L., Exline, H. 1956. Monograph of fossil holothurian sclerites. Bulletin of the Missouri University School of Metallurgy and Mines, Technical series 89 [for 1955], 204 pp.

Gilliland, P.M. 1992. Holothurians in the Blue Lias of southern Britain. Palaeontology 35 (1), 159-210.

Górka, H., Łuszczewska, L. 1969. Holothurian sclerites from the Polish Jurassic and Tertiary. Annales de la Société Géologique de Pologne 39, 361-402.

Krainer, K., Mostler, H., Haditsch, J.G. 1994. Jurassische Beckenbildung in den Nördlichen Kalkalpen bei Lofer (Salzburg) unter besonderer Berücksichtigung der Manga-
nerz-Genese. In: Festschrift zum 60. Geburtstag von Erik Flügel. Abhandlungen der Geologischen Bundesanstalt in Wien 50, 257-293.

Kristan-Tollmann, E. 1986. Holothurien. In: Fischer, R., Jäger, K., Konstantinopolou, A., Kristan-Tollmann, E., Luppold, F.W., Ohm, H.-H. (Eds), Paläontologie einer epikontinentalen Lias-Schichtfolge: Oberes Sinemurium bis Oberes Domerium von Empelde bei Hannover. Facies 15, 53-176.

Lipiec, M. 1992. Some Jurassic holothurian sclerites from the High-Tatric Series of the Tatra Mts., Poland. Geological Quarterly 36 (4), 435-450.

Lord, A., Senior, J.R. 1973. Some Middle Jurassic holothurian sclerites and other microfossils from south Dorset. Proceedings of the Geologists’ Association 84 (1), 31-41.

Ludwig, H. 1891. Ankyroderma musculus (Risso), eine Molpadiide des Mittelmeeres, nebst Bemerkungen zur Phylogenie und Systematik der Holothurien. Zeitschrift für wissenschaftliche Zoologie 51 (4), 569-612.

Metodiev, L., Koleva-Rekalova, E. 2008. Stable isotope records $\left(\delta^{18} \mathrm{O}\right.$ and $\left.\delta^{13} \mathrm{C}\right)$ of Lower-Middle Jurassic belemnites from the Western Balkan Mountains (Bulgaria): palaeoenvironmental application. Applied Geochemistry 23, 2845-2856.

Metodiev, L.S., Savov, I.P., Gröcke, D.R., Wignall, P.B., Newton, R.J., Andreeva, P.V., Koleva-Rekalova, E.K. 2014. Paleoenvironmental conditions recorded by ${ }^{87} \mathrm{Sr} /{ }^{86} \mathrm{Sr}, \delta^{13} \mathrm{C}$ and $\delta^{18} \mathrm{O}$ in late Pliensbachian-Toarcian (Jurassic) belemnites from Bulgaria. Palaeogeography, Palaeoclimatology, Palaeoecology 409, 98-113.

Metodiev, L., Stoylkova, T., Georgieva, M., Koleva-Rekalova, E. 2019. Mercury enrichments as a potential tracer for volcanism in sedimentary successions - examples from the Toarcian in Bulgaria. Review of the Bulgarian Geological Society, National Conference with International Participation "Geosciences 2019" 80 (3), 122-124.

Middelburg, J.J. 2019. Carbon processing at the seafloor. In: Lohmann, G., Mysak, L.A., Notholt, J., Rabassa, J., Unnithan, V. (Eds), Marine Carbon Biogeochemistry. Springer Briefs in Earth System Sciences, 57-75.

Miller, A.K., Kerr, A.M., Paulay, G., Reich, M., Wilson, N.G., Carvajal, J.L., Rouse, G.W. 2017. Molecular phylogeny of extant Holothuroidea (Echinodermata). Molecular Phylogenetics and Evolution 111, 110-131.

Östergren, H. 1898. Das System der Synaptiden (Vorläufige Mitteilung). Öfversigt af Konglida Vetenskaps-akademiens förhandligar 55 (2), 111-120. 
Reich, M. 2003. Holothurians (Echinodermata) from the Upper Cretaceous of the Baltic Sea area: Part 3. Chiridotidae Östergren, 1898. Neues Jahrbuch für Geologie und Paläontologie, Abhandlungen 228 (3), 363-397.

Reich, M. 2012. On Mesozoic laetmogonid sea cucumbers (Echinodermata: Holothuroidea: Elasipodida). Zoosymposia $7,185-212$.

Reich, M. 2013. How many species of fossil holothurians are there? In: Johnson, C. (Ed.), Echinoderms in a Changing World. Taylor \& Francis Group, London, 23-51.

Reich, M. 2014. Supplement to: 'How many species of fossil holothurians are there?'. Göttingen Contributions to Geosciences 77, 161-162.

Reich, M. 2015. Supplement 2 to "How many species of fossil holothurians are there?”. Zitteliana A 55, 121-122.

Reolid, M., Duarte, L.V., Rita, P. 2019. Changes in foraminiferal assemblages and environmental conditions during the T-OAE (Early Jurassic) in the northern Lusitanian Basin, Portugal. Palaeogeography, Palaeoclimatology, Palaeoecology 520, 30-43.

Rioult, M. 1961. Les sclérites d'Holothuries fossiles du Lias. Colloque sur le Lias français, Chambéry 1960, Mémoires du Bureau de Recherches Géologiques et Minières 4, 121-153.

Roberts, D., Gebruk, A., Levin, V., Manship, B.A.D. 2000. Feeding and digestive strategies in deposit-feeding holo- thurians. In: Gibson, R.N., Barnes, M. (Eds), Oceanography and marine biology 38, 257-310.

Sapunov, I., Metodiev, L. 2007. Main features of the Jurassic in Bulgaria. Comptes rendus de l'Académie bulgare des Sciences 60 (2), 169-178.

Schlumberger, C. 1888. Note sur les Holothuridées fossiles du Calcaire Grossier. Bulletin de la Société géologique de France 3 (16), 437-441.

Schlumberger, C. 1890. Seconde note sur les Holothuridées fossiles du Calcaire Grossier. Bulletin de la Société géologique de France 3 (18), 191-206.

Stefanov, S.A. 1970. Einige Holothurien-Sklerite aus der Trias in Bulgarien. Review of the Bulgarian Geological Society 31 (1), 41-50.

Valiela, I. 2015. Marine Ecological Processes (Third Edition). Springer-Verlag, New York, Heidelberg, Dordrecht, London, $701 \mathrm{pp}$.

Whidborne, C.F. 1883. Notes on some Fossils, chiefly Mollusca, from the Inferior Oolite. Quarterly Journal of the Geological Society London 39, 487-540.

Xu, Q., Hamel, J.-F., Mercier, A. 2015. Chapter 10. Feeding, digestion, nutritional physiology and bioenergetics. In: Yang, H., Hamel, J.-F., Mercier, A. (Eds), The sea cucumber Apostichopus japonicus. History, biology and aquaculture. Elsevier Academic Press, 153-176 (http://dx.doi. org/10.1016/B978-0-12-799953-1.00010-6). 